\title{
Three dimensions of modern terrorism in the European Union
}

Due to the political, economic and media importance of the European Union, as well as on account of its cultural and social diversification, the EU constitutes a prominent target of terrorist attacks. The scale, character and specific nature of these attacks are well evidenced by the annual reports by Europol, including the latest TE-SAT 2018, European Union Terrorism Situation and Trend Report (TE-SAT, 2018).

This paper aims to discuss the nature and characteristics of modern terrorism in the European Union in recent years, with particular emphasis given to the latest data published by Europol in 2018. ${ }^{1}$ The issues addressed include, among other things, the threat of terrorism in the EU posed by jihadist terrorists, separatists, and left-, and right-wing extremists. Another issue concerns individuals arrested and convicted in the EU for terrorist activity.

The main thesis of this paper is that terrorism in the EU has a vertical, horizontal and transcendent dimension. The vertical dimension is related to the extensive range of innovative tactics and strategy. The horizontal dimension refers to the potential of various targets being attacked in individual EU member states. Finally, the transcendent dimension concerns the diverse ideological inspiration of terrorists, be it Islam, separatism, and extreme left-, or right-wing ideology.

The number of failed, foiled and completed terrorist attacks consistently fell over the period between 2014 and 2016 in the European Union. In 2014, there were 226 attacks, 193 in 2015 and 142 in 2016. A deviation to this trend occurred in 2017 which saw a significant rise in the number of attacks (205). The United Kingdom (UK) experienced the highest number of attacks (107), followed by France (54), Spain (16), Italy (14), Greece (8), Belgium and Germany (2 attacks each), and Finland and Sweden (one attack each). In 2017, 68 victims died as a result of terrorist attacks and 844 people were injured, compared to 142 fatalities and 379 casualties in 2016. A majority were the result of jihadist terrorist attacks (62 out of 68 fatalities and 819 out of 844 casualties).

Contrary to common belief, the majority of the terrorist attacks reported in the European Union are not inspired by Islamism. For instance, in 2013 none of the 152 failed, foiled and completed attacks was related to Islamism. In 2014, only two out of 199 incidents were classified as Islamist. In 2015, out of the total number of 211 attacks, 17 were inspired by Islamism, 65 by separatist trends, 13 by the extreme left,

${ }^{1}$ To learn about the methodology employed by Europol for the purpose of registering and classifying terrorist attacks, their victims and perpetrators, see: Methodology (TE-SAT, 2018). 
nine by the extreme right, and 109 attacks were not classified as any of the above ("not specified"). The attacks in 2016 (142) were clearly dominated by separatist motivation (99), while the remaining ones were classified as follows: extreme left-wing (27), jihadist (13), not specified (2), and extreme right-wing (1) (TE-SAT, 2014, 2015, 2016, 2017).

\section{Graph 1. Number of failed, foiled or completed attacks in EU from 2014 to 2017}

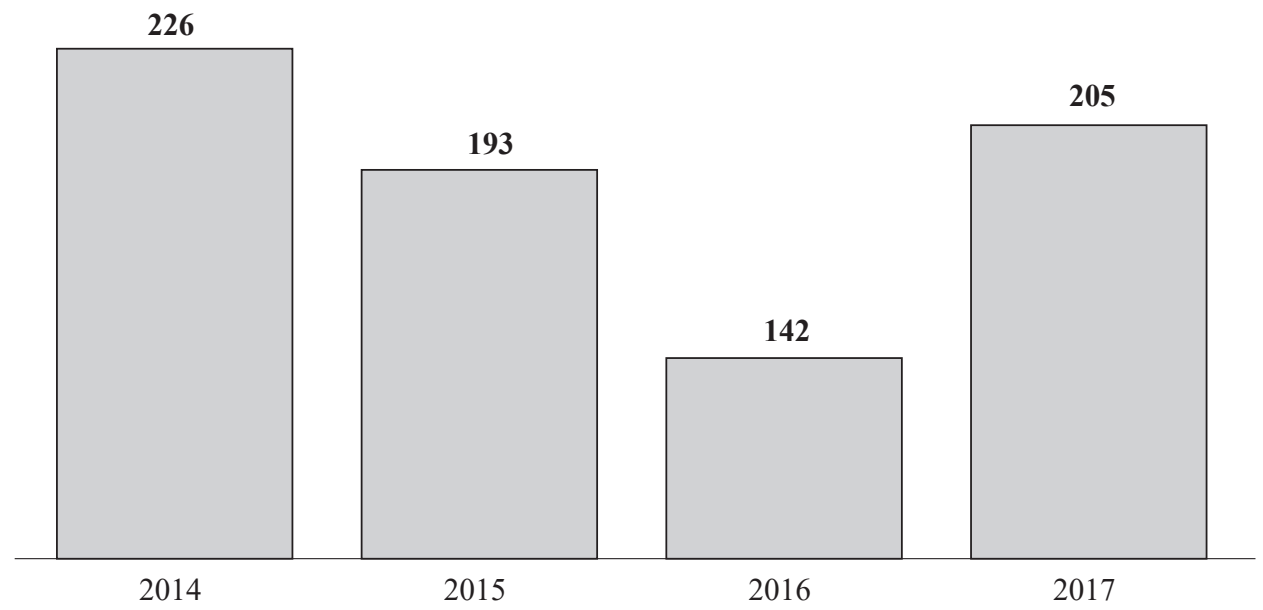

Source: TE-SAT 2018, European Union Terrorism Situation and Trend Report 2018, Europol, www.europol.europa.eu, 22.11.2018.

The most recent report produced by Europol for 2017 shows that the majority of all attacks reported (205) were separatist attacks (137), followed by jihadist (33), extreme left-wing (24), not specified (6), and extreme right-wing (5). Separatist attacks were reported in the UK (88), France (42) and Spain (7). Islamist terrorists attacked in the UK (14), France (11), Spain and Belgium (2 each) as well as in Finland, Germany, Italy and Sweden (1 each). Attacks inspired by extreme left-wing ideology were reported in Greece (8), Italy and Spain (7 each) as well as in Germany and France (1 each). Not specified cases were reported in Italy (6), and extreme right-wing cases in the UK (5) (TE-SAT, 2018).

Failed, foiled and completed attacks in 2017 per EU

Table 1 member state and per affiliation

\begin{tabular}{|l|c|c|c|c|c|c|c||}
\hline Member State & Jihadist & Left-wing & Right-wing & Separatist & $\begin{array}{c}\text { Single } \\
\text { issue }\end{array}$ & $\begin{array}{c}\text { Not } \\
\text { specified }\end{array}$ & Total \\
\hline \multicolumn{1}{|c|}{1} & 2 & 3 & 4 & 5 & 6 & 7 & 8 \\
\hline Belgium & 2 & - & - & - & - & - & $\mathbf{2}$ \\
\hline Finland & 1 & - & - & - & - & - & $\mathbf{1}$ \\
\hline France & 11 & 1 & - & 42 & - & - & $\mathbf{5 4}$ \\
\hline Germany & 1 & 1 & - & - & - & - & $\mathbf{2}$ \\
\hline
\end{tabular}




\begin{tabular}{||l|c|c|c|c|c|c|c||}
\hline \multicolumn{1}{|c|}{1} & 2 & 3 & 4 & 5 & 6 & 7 & 8 \\
\hline Greece & - & 8 & - & - & - & - & $\mathbf{8}$ \\
\hline Italy & 1 & 7 & - & - & - & 6 & $\mathbf{1 4}$ \\
\hline Spain & 2 & 7 & - & 7 & - & - & $\mathbf{1 6}$ \\
\hline Sweden & 1 & - & - & - & - & - & $\mathbf{1}$ \\
\hline United Kingdom & 14 & - & 5 & 88 & - & - & $\mathbf{1 0 7}$ \\
\hline Total & $\mathbf{3 3}$ & $\mathbf{2 4}$ & $\mathbf{5}$ & $\mathbf{1 3 7}$ & $\mathbf{0}$ & $\mathbf{6}$ & $\mathbf{2 0 5}$ \\
\hline
\end{tabular}

Source: TE-SAT 2018, European Union Terrorism Situation and Trend Report 2018, Europol, www.europol.europa.eu, 13.11.2018.

Considerable growth was noted in the number of arrests for terrorism in the EU from 2013 to 2015. In 2013, there were 535 such cases, in $2014-774$ and in 2015, as many as 1,077. This trend deviated in 2016, which saw a slight drop to 1,002 and a further grow to 1219 in 2017. It is therefore alarming that the number of persons arrested for jihad-motivated terrorist activity has been on the rise, accounting for 159 arrests in 2012, 395 in 2014 and as many as 718 in 2016. This number remained at a similar level in 2017 (705). The proportion of jihadist terrorists compared to other terrorists grew from ca. $50 \%$ of all arrests in 2014 to ca. $70 \%$ in 2016 . This indicator remained at a comparable level in 2017.

In 2016, France saw the largest number of arrested Islamists (429), followed by Spain (69), Belgium (62), the Netherlands (36), Austria (30), Italy (28), and Germany (25). In Poland and Bulgaria five such arrests were made. In 2017, out of 1219 individuals arrested, 705 were jihadist terrorists. They were apprehended mainly in UK (412), France (411) and Spain (91). On top of that, there were 30 separatists arrested (mainly in France - 13 and Spain -10), 36 left-wing extremists (mainly in Greece - 12, Italy -11 and France - 10) and 20 right-wing extremists (in France - 15, Germany - 3, Italy -2). A further 428 arrests were not specific.

In 2017, a definite majority of arrests (660) were performed on suspicion of participating in activities of a terrorist group; planning; and preparing attacks. 73 persons were arrested on suspicion of terrorism propaganda or financing of terrorism. 28 arrests were performed for travelling to, or from territories controlled by various terrorist organizations, primarily by ISIS and al-Qaeda (Wejkszner, 2016), compared to 141 such arrests in 2015 and 77 in 2016 (TE-SAT, 2016-2017-2018).

The number of EU citizens who have recently travelled to Iraq or Syria with the purpose of reaching territories controlled by ISIS is estimated by Europol at ca. 5,000. In the late 2017 , ca. 2,500 of them continued fighting there, whereas 1,500 had returned to the EU (mainly to Belgium, Germany, France and UK), and around one thousand had been killed (Wojciechowski, Wejkszner, 2018).

The average age of individuals arrested on suspicion of terrorism in the European Union in 2017 was 30 years; $45 \%$ of them were in the $20-30$ age bracket and $25 \%$ in the $30-40$ one. Ca. $50 \%$ of individuals arrested were EU citizens, a percentage comparable to earlier years (58\% in 2015, 43\% in 2016). The percentage of females (citizens of EU member states) arrested on suspicion of jihadist activity dropped from $26 \%$ in 2016 to $16 \%$ in 2017 , returning to the level from 2015, when their number accounted for $18 \%$. 
Arrests in 2017 per EU member state and per affiliation

\begin{tabular}{|l|r|c|c|c|c|r||}
\hline \multicolumn{1}{|c|}{ Member State } & Jihadist & Left-wing & Separatist & Right-wing & $\begin{array}{c}\text { Not } \\
\text { specified }\end{array}$ & Total \\
\hline France & 373 & 10 & 13 & 15 & - & $\mathbf{4 1 1}$ \\
\hline Spain & 78 & 3 & 10 & - & - & $\mathbf{9 1}$ \\
\hline Germany & 52 & - & 3 & 3 & - & $\mathbf{5 8}$ \\
\hline Belgium & 50 & - & - & - & - & $\mathbf{5 0}$ \\
\hline Austria & 46 & - & 2 & - & - & $\mathbf{4 8}$ \\
\hline Netherlands & 28 & - & 2 & - & 5 & $\mathbf{3 5}$ \\
\hline Italy & 26 & 11 & - & 2 & - & $\mathbf{3 9}$ \\
\hline Denmark & 14 & - & - & - & 3 & $\mathbf{1 7}$ \\
\hline Greece & 3 & 12 & - & - & - & $\mathbf{1 5}$ \\
\hline Bulgaria & 14 & - & - & - & - & $\mathbf{1 4}$ \\
\hline Ireland & 3 & - & - & - & 8 & $\mathbf{1 1}$ \\
\hline Finland & 9 & - & - & - & - & $\mathbf{9}$ \\
\hline Hungary & 2 & - & - & - & - & $\mathbf{2}$ \\
\hline Poland & 2 & - & - & - & - & $\mathbf{2}$ \\
\hline Romania & 2 & - & - & - & - & $\mathbf{2}$ \\
\hline Czech Republic & 1 & - & - & - & - & $\mathbf{1}$ \\
\hline Portugal & 1 & - & - & - & - & $\mathbf{1}$ \\
\hline Sweden & 1 & - & - & - & - & $\mathbf{1}$ \\
\hline United Kingdom & - & - & - & - & 412 & $\mathbf{4 1 2}$ \\
\hline Total & $\mathbf{7 0 5}$ & $\mathbf{3 6}$ & $\mathbf{3 0}$ & $\mathbf{2 0}$ & $\mathbf{4 2 8}$ & $\mathbf{1 2 1 9}$ \\
\hline
\end{tabular}

Source: TE-SAT 2018, European Union Terrorism Situation and Trend Report 2018, Europol, www.europol.europa.eu (13.11.2018).

Another important indicator is the number of verdicts passed for terrorism in the EU in 2017. Eurojust reported 569 such cases, compared to 513 in 2015, and 580 in 2016. In 2017, the vast majority of verdicts (352) concerned jihadist terrorism. Further verdicts included 49 for separatist, 36 for left-wing, and four for right-wing terrorism; 128 cases remained not specified. The ideological profile of individuals sentenced in individual states varied. Jihadist terrorists clearly prevailed in France (114 out of 122 cases). The situation was similar in Belgium (81 out of 85 persons). In Spain verdicts for jihadist terrorism were accompanied by those for separatist (26) and left-wing (14) terrorism (TE-SAT, 2018).

Table 3

Number of verdicts in 2017 per EU member state and per type of terrorism, as reported to Eurojust

\begin{tabular}{||l|c|c|c|c|c|c||}
\hline \multicolumn{1}{|c|}{ Member State } & Jihadist & Separatist & Left-wing & Right-wing & $\begin{array}{c}\text { Not } \\
\text { specified }\end{array}$ & Total \\
\hline \multicolumn{1}{|c|}{1} & 2 & 3 & 4 & 5 & 6 & 7 \\
\hline Austria & 18 & - & - & - & - & $\mathbf{1 8}$ \\
\hline Belgium & 81 & 4 & - & - & - & $\mathbf{8 5}$ \\
\hline Czech Republic & 3 & - & 5 & - & - & $\mathbf{8}$ \\
\hline Denmark & 4 & - & - & - & - & $\mathbf{4}$ \\
\hline Estonia & 2 & - & - & - & - & $\mathbf{2}$ \\
\hline
\end{tabular}




\begin{tabular}{||l|r|r|r|r|r|r||}
\hline \multicolumn{1}{|c|}{1} & 2 & 3 & 4 & 5 & 6 & \multicolumn{1}{c||}{} \\
\hline Finland & 2 & - & - & - & - & $\mathbf{2}$ \\
\hline France & 114 & 8 & - & - & - & $\mathbf{1 2 2}$ \\
\hline Germany & 27 & 3 & - & 4 & - & $\mathbf{3 4}$ \\
\hline Greece & 2 & - & 17 & - & - & $\mathbf{1 9}$ \\
\hline Italy & 23 & - & - & - & - & $\mathbf{2 3}$ \\
\hline Lithuania & - & 1 & - & - & 1 & $\mathbf{2}$ \\
\hline Netherlands & 37 & 7 & - & - & 2 & $\mathbf{4 6}$ \\
\hline Poland & 4 & - & - & - & - & $\mathbf{4}$ \\
\hline Portugal & 1 & - & - & - & - & $\mathbf{1}$ \\
\hline Spain & 31 & 26 & 14 & - & - & $\mathbf{7 1}$ \\
\hline Sweden & 3 & - & - & - & - & $\mathbf{3}$ \\
\hline United Kingdom & - & - & - & - & 125 & $\mathbf{1 2 5}$ \\
\hline Total & $\mathbf{3 5 2}$ & $\mathbf{4 9}$ & $\mathbf{3 6}$ & $\mathbf{4}$ & $\mathbf{1 2 8}$ & $\mathbf{5 6 9}$ \\
\hline
\end{tabular}

Source: TE-SAT 2018, European Union Terrorism Situation and Trend Report 2018, Europol, www.europol.europa.eu, 20.11.2018.

The report produced by Europol for 2016 (TE-SAT, 2017) and the analysis performed by the then Director of Europol Rob Wainwright indicated that terrorists are becoming increasingly interested in gaining publicity in the media, which translates into their choice of the location, target and form of attacks. This is well exemplified by the terrorist attacks carried out in the vicinity of sports facilities, concert halls, shopping malls and busy transportation routes. Another disturbing observation concerns the fact that terrorists operating in the EU are determined and increasingly better prepared professionally. A particularly dangerous scenario involves, for instance, a sequential attack, which means a series of attacks performed simultaneously at different locations. This was the scenario of the 2015 attack in Paris, among others. In many cases, the terrorists are better trained and it is considerably more difficult both to disable them and to identify their mutual connections.

In the opinion of the authors of the TE-SAT 2017 report, it is difficult to identify a direct dependence between EU immigration policy and the scale of terrorist attacks. The data collected suggests that terrorist attacks were typically carried out by individuals who had long lived in the EU, who had frequently been born here and are citizens of EU member states. While, in the period considered, there were cases reported of individuals who entered the EU and executed terrorist attacks, these were isolated instances. The analyses published in the TE-ST 2018 largely confirm the same observations.

Another theme is the counter-terrorist measures taken by the European Union. Among their drawbacks, the report indicates the lack of appropriate instruments to counter the operation of armed drones which may be used by terrorists, among others. That this threat is a real one follows from the incident in Caracas on August 4, 2018, when several drones exploded among an audience listening to a speech being delivered by the President of Venezuela, Nicolas Maduro, one of the explosions taking place in the vicinity of the presidential rostrum. Positive outcomes of EU counter-terrorism policy in 2017 include the successful curbing of online Islamist propaganda dissemination. Reportedly, ca. $90 \%$ of all posts which encourage readers to carry out attacks or instruct how to perform such attacks are swiftly removed from the internet and their 
authors are usually identified and detained. Nevertheless, experts from Europol admit that in 2018 Islamist propaganda is a permanent element of the internet, among others on Blogger, Contactime, Facebook, Flickr, Google+, Issuu, Paltalk, Twitter, and Youtube.

The TE-SAT 2018 report stresses the issue of partially changed operating methods of terrorists in the EU. For instance, the number of attacks involving the use of military-grade explosives and home-made explosives has dropped in favor of attacks involving firearms, the number of which has increased. The report stresses that terrorists frequently procure weapons and explosives in conflict zones, where they engage in cooperation with organized crime. It is also highlighted that the internet continues to feature an abundant number of instructions on how to make explosives. Such instructions are spread via social media and encrypted messages, among other things.

Another crucial issue addressed is the still unsolved problem of terrorist financing. 2017 saw the breakup of a money laundering network working for organized crime and terrorists linked to Hezbollah. Cases of transferring money to the families or supporters of terrorists in North Africa and the Middle East have also been reported. Interestingly, the majority of such financial resources were not transferred to, but from Europe through non-profit organizations and UAE institutions.

The following conclusions follow from the most recent report by Europol and the analysis of terrorist threat in the European Union.

1. Terrorism in the EU has a vertical, horizontal and transcendent dimension. The vertical dimension is related to the extensive range of innovative tactics and strategy terrorists use. Some of them may be highly dangerous and innovative at the same time. The horizontal dimension refers to the potential of different targets being attacked in individual EU member states, as exemplified by the terrorist attacks carried out in eight states in 2016, and in nine states in 2017. The transcendent dimension concerns the diverse ideological inspiration of the terrorists operating on EU territory. In 2017, $67 \%$ of attacks were carried out by separatists, $16 \%$ by jihadist terrorists, $12 \%$ by leftwing, $3 \%$ by right-wing extremists, and the remaining were not specified.

2. Terrorism is likely to escalate again, in particular Islamist terrorism. This threat will not concern only France, Belgium, the Netherlands and UK, but also other EU member states that have not been attacked in the past. This is the outcome of numerous factors, including that, having been defeated in Syria and Iraq, ISIS is in need of spectacular successes. This will also be part of the strategy of 'opening new fronts' and performing attacks in new locations, by taking advantage of the determination and radicalism of some of ISIS supporters. The former Director of Europol Rob Wainwright has repeatedly addressed this issue, observing that ISIS has resolved to send 'fanatics' to Europe in order to divert people's attention from its successive defeats in Syria and Iraq.

3. Continued mass influx of migrants to the European Union may increase the threat of terrorist attacks. On the one hand, this concerns the activities of Islamic terrorists hiding among, or seeking the support of immigrants and refugees. On the other hand, cases of extremist terrorism, performed by right-wing, left-wing and separatist groups who, for various reasons, either oppose or support the process of immigrant/refugee influx to the EU has to be taken into consideration. 
4. In the case of Islamist terrorism, the greatest threat is not posed by former ISIS fighters who, for various reasons and in various ways, have returned to the EU. These can usually be supervised. The same pertains to Islamists living in the EU who carry out radical activities on internet forums and in mosques, among other things. The greatest threat is posed by individuals who identify with Islamism and are prone to terrorist operations but do not reveal their opinions in public.

5. Terrorists will make increasing use of commonly accessible and unrefined tools, such as knives, axes, speeding vehicles, and so on. At the same time, however, there is a growing threat of Islamists using weapons of mass destruction, such as chemical, biological and radioactive weapons, as well as cyberterrorism and drones. This is the scenario the UK Minister of State for Security, Ben Wallace, warned against in January 2017, speaking about a jihadist laboratory in Morocco, discovered by the police, which might have served the purpose of producing chemical and biological weapons.

6. The threat of terrorists using biological weapons is grossly underestimated. Experts point to the possibility of using bubonic plague bacteria. At the beginning of 2017, the World Health Organization officially declared the bubonic plague to pose the greatest biological threat globally, due to the ease with which it can be obtained, the fast spread of the disease, extremely high mortality rate (90-100\% in some varieties, for instance pneumonic plague), the lack of a vaccine, the inefficiency of antibiotics that have so far been used, and the ease with which the bacteria can be brought to the territory of a given state.

7. Another potential terrorist threat is exemplified by the situation that occurred in Germany in mid-June 2018. The German Federal Prosecutor's Office reported the arrest of a Tunisian, Sief Allah H., in Cologne on charges of possession of a biological weapon. A large quantity of dangerous ricin was found in his apartment. The threat related to this case was named by investigators "the largest potential threat ever found in Europe." The posts of the Tunisian suggested that he sympathized with ISIS. The German authorities were informed about the suspect by US special services, who became alarmed by the online purchases of the Tunisian man. Among other things, he purchased thousands of castor oil plant seeds, which are the source of ricin. In the opinion of many experts, the castor oil plant is one of the most poisonous plants in the world, due to its chemical composition. The Robert Koch Institute in Germany defined ricin, which can be obtained from the castor oil plant, as a "potential biological weapon." Even at low concentrations, ricin can be fatal, leading to severe damage of various internal organs within 36-48 hours.

8. The present activities of the European Union and of the majority of EU member states with respect to countering terrorism still have to be considered insufficient. This primarily concerns the allocation of too conservative financial resources and the lack of fully-fledged international collaboration, including swift and exhaustive information exchange. Unfortunately, the 'multi-speed' European policies are also reflected in countering terrorism. This is related to the operation of various, and frequently incompatible, terrorist data gathering systems and the different degree of commitment and cooperation between individual EU member states and their services in combatting terrorist threat. Bibi van Ginkel from the International Centre for Counter-Terrorism was right to remark that "not all EU member are ready to share intelligence to the same degree" (Ginkel, 2017). 


\section{Bibliography}

Ginkel B. (2017), Countering and Preventing the Threat of Terrorism and Violent Extremism: From the International and European to the National and Local Levels, CIDOB 2017, www.cidob. org/.../29-36_BIBI\%20VAN\%20GINKEL.PDF.

Murphy C. (2012), EU Counter-Terrorism Law. Pre-Emption and the Rule of Law, London.

Nesser P. (2016), Islamist Terrorism in Europe: A History, Oxford.

Routledge Handbook of Terrorism and Counterterrorism (2019), ed. A. Silke, London-New York.

TE-SAT (2014), European Union Terrorism Situation and Trend Report 2014, Europol, www.europol.europa.eu.

TE-SAT (2015), European Union Terrorism Situation and Trend Report 2015, Europol, www.europol.europa.eu.

TE-SAT (2016), European Union Terrorism Situation and Trend Report 2016, Europol, www.europol.europa.eu.

TE-SAT (2017), European Union Terrorism Situation and Trend Report 2017, Europol, www.europol.europa.eu.

TE-SAT (2018), European Union Terrorism Situation and Trend Report 2018, Europol, www.europol.europa.eu.

Wejkszner A. (2016), Państwo Islamskie. Narodziny nowego kalifatu?, Warszawa.

Wejkszner A. (2017), Globalna sieć Al-Kaidy. Nowe państwo islamskie?, Warszawa.

Wojciechowski S. (2013), The Hybridity of Terrorism. Understanding Contemporary Terrorism, Berlin.

Wojciechowski S. (2017), Reasons of Contemporary Terrorism. An Analysis of Main Determinants, in: Radicalism and Terrorism in the 21st Century, eds. A. Sroka, F. Castro-Rial Garrone, R. Torres Kumbrian, Frankfurt am Main-Bern-Bruxelles-New York-Oxford-WarszawaWien.

Wojciechowski S. (2018), Światowy wirus terroryzmu, "Rocznik Strategiczny” 2017/2018, Przeglad sytuacji politycznej, gospodarczej i wojskowej w środowisku międzynarodowym Polski, Warszawa.

Wojciechowski S., Osiewicz P. (2017), Zrozumieć współczesny terroryzm. Wybrane aspekty fenome$n u$, Warszawa.

Wojciechowski S., Wejkszner A. (2018), “Foreign fighters” a przenikanie zagrożeń terrorystycznych przez granice UE, InfoSecurity 24, https://www.infosecurity24.pl/foreign-fighters-a-przenikanie-zagrozen-terrorystycznych-przez-granice-ue, 30.01.2018.

Wojciechowski S., Wejkszner A. (2018), Unia Europejska wobec zagrożenia ze strony tzw. zagranicznych bojowników, InfoSecurity 24, https://www.infosecurity24.p1/foreign-fighters-aprzenikanie-zagrozen-terrorystycznych-przez-granice-ue, 23.01.2018.

\section{Summary}

Due to the political, economic and media importance of the European Union, as well as on account of its cultural and social diversification, the EU constitutes a prominent target of terrorist attacks. The scale, character and specific nature of these attacks are well evidenced by the annual reports by Europol. This paper aims to discuss the nature and characteristics of modern terrorism in the European Union in recent years with particular emphasis given to the latest data published by Europol in 2018. The issues addressed include, among other things, the threat of terrorism in the EU posed by jihadist terrorists, separatists, and left-, and 
right-wing extremists. Another issue concerns individuals arrested and convicted in the EU for terrorist activity.

The main proposal made in this paper is that terrorism in the EU has a vertical, horizontal and transcendent dimension. The vertical dimension is related to the extensive range of innovative tactics and strategy. The horizontal dimension refers to the potential of attacking various targets in individual EU member states. Finally, the transcendent dimension concerns the diverse ideological inspiration of terrorists, be it Islam, separatism, extreme left-, or right-wing ideology.

Key words: terrorism, terrorist threat in the European Union, Europol, vertical, horizontal and transcendent dimensions of terrorism

\section{Trzy wymiary współczesnego terroryzmu w Unii Europejskiej}

\section{Streszczenie}

Unia Europejska między innymi ze względu na znaczenie polityczne, ekonomiczne czy medialne, a także z uwagi na występujące w niej różnice kulturowo-społeczne jest ważnym celem ataków terrorystycznych. Ich skalę, charakter czy specyfikę dobrze ukazują coroczne raporty Europolu. Celem tekstu jest zaprezentowanie istoty oraz charakterystyki współczesnego terroryzmu występującego w Unii Europejskiej w ciągu ostatnich kilku lat, ze szczególnym uwzględnieniem najnowszych danych zaprezentowanych przez Europol w 2018 roku. Wśród przedstawionych kwestii poruszono m.in. problem zagrożenia terrorystycznego w UE ze strony dżihadystów, separatystów czy lewicowych oraz prawicowych ekstremistów. Przeanalizowano też zagadnienie osób aresztowanych i skazanych w Unii Europejskiej za działalność terrorystyczną. Główną tezą tekstu jest stwierdzenie, że terroryzm występujący na terytorium UE ma zarówno wymiar wertykalny, horyzontalny, jak i transcendentalny. Pierwszy z nich (wertykalny) związany jest ze stosowaniem przez terrorystów bardzo różnych i wciąż nowych elementów taktyki czy strategii. Drugi (horyzontalny) odnosi się do możliwości atakowania różnorodnych celów w poszczególnych państwach członkowskich UE. Natomiast trzeci wymiar transcendentalny dotyczy zróżnicowanej motywacji ideologicznej terrorystów. Ma ona nie tylko charakter islamistyczny, ale także np. separatystyczny, skrajnie prawicowy czy lewicowy.

Słowa kluczowe: terroryzm, zagrożenie terrorystyczne w Unii Europejskiej, wertykalny, horyzontalny i transcendentalny wymiar terroryzmu 
